development of this work must have been astounded at the number of inhabited caves which it revealed, at the extent and variety of cave faunas (the index to the animals itself occupies 96 pages), and at the vast number of papers which have been written about them. The completed work is in three volumes, the first including introduction and bibliography (pp. 108); the second containing a list of the caves, with literature references to each and the names of the animals recorded from each (pp. 616); and the last containing a systematic list of the animals, with references to the caves in which they have been found and to the recorders (pp. 918). The three volumes are thoroughly indexed, one index of 46 pages referring to the caves, the other (96 pp.) to the animals. The bibliography is itself alphabetically arranged so that it serves as a guide to authors. The Supplement carries the information about cave faunas up to tho end of 1935 .

\section{Work of the Central Midwives Board}

The Central Midwives Board, which controls and regulates the work of practising midwives, has issued its annual report for the year onded March 31, 1939 (H.M. Stationery Office. $4 d$. net). The number of women practising as midwives in England and Wales in 1938 was 16,761 , some 700 less than in the provious year. During the year covered by the report, new training and oxamination rules of the Board came into operation. The training rules requiro practising midwives to attend courses of instruction from time to time. A report on the examinations held during the year is included, together with notes of various decisions by the Board on midwives' training, etiquetto and practice. Tho report also refers to preparatory arrangemonts made by the Board for an efficient midwifery service during a national emergency.

\section{Hospital Schools in the United States}

Speciar educational facilities should obviously be provided for children who must spend weeks, months or even years in a hospital or sanatorium. Some attempt to meet this need has been made in the United States, and information concerning this service has been collected (U.S. Department of the Interior. Bulletin, No. 17 ; 1938). It is estimated that fifty or sixty thousand children in American hospitals need educational facilities, but less than eight thousand appear to be receiving tuition. It is pointed out that the hospital school has three values : therapeutic, vocational and general educational. It aids physical recovery by keeping the child's mind occupied and away from his misfortune.

\section{Bibliography of Seismology}

We have just received vol. 13, No. 1, items 42601378 of the Bibliography of Seismology, published by the Cominion Observatory at Ottawa. In this number there are fifteen collaborators from Furope, North America and New Zealand, notable absences being South America and U.S.S.R., where it is known that seismological work is being done. In addition to the particular studies of individual earthquakes, mathematical seismology and general earth structure, a considerable number of the listed papers deal with microseisms and geophysical prospecting. The latter becomes increasingly important as details aro worked out and apparatus becomes more applicable to the particular problems involved, needing to be robust, sensitive, and yet transportable. It is noteworthy that item 4342 is of six patents concerned with seismic prospecting, four being U.S. patents, one Canadian and one U.S.S.R.

\section{Seismology in the Antarctic}

WE learn from Capt. N. H. Heck that it is proposed to instal a seismograph, if possible on a rock foundation, at a base of the forthcoming United States Expedition to the Antarctic. This, along with the stations in South Africa, South America, Australia and New Zealand will bo extremely useful in determining epicentres in the southern hemisphere where seismographic stations are all too few, and on the continent of Antarctica in particular, the seismic history of which is little known. Miss Bellamy's catalogue of 1913-1930 shows seven epicentres actually located on the continent, and the Milne seismograph of the British Antarctic Expedition from March 1902 until November 1903 (lat. $77^{\circ} 51^{\prime}$ S., long. $166^{\circ} 45^{\prime}$ E.) recorded 135 earthquakes, of which approximately $\mathbf{7 5}$ were local though none was strong enough to be felt by the explorers.

\section{Earthquake in the New Hebrides}

ON instrumental reports from the seismographic stations of Georgetown, Tucson, St. Louis, Honolulu, Pittsburg, Manila, Weston, Fordham, Pasadena, Hong Kong, Phu Lien, Apia, Huancayo and Lincoln, tho United States Coast and Geodetic Survey in co. operation with Science Service and the Jesuit Seismological Association has determined the epicentre of the earthquake of October 17, 1939, as having been provisionally in islands of the New Hebrides group in the Pacific Ocean. More precisely, the epicentre was situated in the sea between the islands of Malekula, Ambrim and Pentecost. This is a seismic area particularly liable to deep focus earthquakes, and this shock was no exception, being situated at a depth probably near $100 \mathrm{~km}$.

\section{Royal Academy of the Lincei}

Tre Secretary of tho Royal Academy of Italy announces that the Royal Academy of the Lincei has been amalgamated with the Royal Academy of Italy, which has taken over all the activities of the Lincei. As from July 1, 1939, the publications of the Academy of the Lincei will form part of the combined Atti della Reale Academia d'Italia, which will be divided into Rendiconti and Memorie of the class of moral and historical sciences and of the class of physical, mathematical and natural sciences. The publication of the Notizie degli Scavi will be continued without interruption by the Italian Academy. The Royal Academy of Italy will be pleased to send its 
publications to those institutions which received the publications of the Royal Academy of the Lincei under a system of exchange.

\section{Chemical Club}

Tre Chemical Club, 2 Whitehall Court, London, S.IV.1, has arranged a series of 'talks' similar to those held at the Club last winter. They will, however, be briefer, and will be held after luncheon in view of the War. The first talk of the season will bo given by Mr. James Kowley, chief chemist of the Royal Dutch Shell Group, on Monday, December 11, at 2 o'clock at the Club. The title will be "The Intrusions of Petroleum", and it is oxpected to deal with the increased range of products being manufactured by tho petroleum industry which 'intrude' upon the organic chemical market. At the annual general meeting of the Club on November 14, a resolution was adopted that the facilities of the Club should be thrown open during hostilities, at a nominal subscription, to those temporarily engaged in London on Government work.

\section{Chadwick Public Lectures}

IN September last it was decided, in consequence of the War, to postpone the Chadwick Public Lectures which were to have been delivered this autumn. The Trustees have now resolved to resume the lectures, and the first lecture is to be delivered on Tuesday, December 12, at 2.30 p.m., at tho Royal Society of Tropical Medicine and Hygiene, 26 Portland Place, W.1, when Sir William Savage is to speak on "The Health Aspects of Canned Foods". The lectures for the spring programme, 1940, will deal generally with public health matters and the War, and will be announced in due course.

\section{National Institute of Sciences of India}

AT a meeting of the Council of the National Institute of Sciences of India, held on October 6 in the rooms of the Royal Asiatic Society of Bengal, Calcutta, the following were elected fellows of the Institute: Ordinary Fellows: Dr. K. Banerjeo, reader in physics, University of Dacca; Prof. F. R. Bharucha, professor of botany and head of the Department, Royal Institute of Science, Bombay; Dr. R. N. Ghosh, reader in physics, University of Allahabad; Prof. H. K. Mookerjee, University professor of zoology and head of tho Department, University of Calcutta; Prof. V. V. Narlikar, professor of mathematics and head of the Department, Benares Hindu University ; Dr. C. G. Pandit, officiating director of the King Institute of Preventive Medicine, Guindy, Madras ; Major C. L. Pasricha, professor of pathology and bacteriology, School of Tropical Medicine, Calcutta; Prof. L. Rama Rao, professor of geology, University of Mysore; Dr. M. Sharif, entomologist, Haffkine Institute, Bombay; Dr. K. Venkataraman, director of the University of Bombay Laboratories of Chemical Technology and Textilo Chemistry. Honorary Fellows : Dr. E. V. Appleton, secretary of the Department of Scientific and Industrial Research of Great Britain; Prof. Charles W. Edmunds, professor of pharmacology and therapeutics, University of Michigan Medical School; Prof. R. A. Fisher, Galton professor of eugenics in University College, London; Prof. Waldemar Lindgren, emeritus pro. fessor of geology, Massachusetts Institute of Technology, whose death on November 3 is announced on p. 970 .

\section{Royal Society Officers and Council}

The following is a list of thoso elected as officers and council of the Royal Society at the anniversary meeting held on November 30 : President, Sir William Bragg; Treasurer, Prof. T. R. Merton; . Secretaries, Prof. A. V. Hill, Prof. A. C. G. Egerton; Foreign Secretary, Sir Albert Seward; Other Members of Council, Prof. F. C. Bartlett, Prof. P. G. H. Boswell, Prof. F. 'T. Brooks, Dr. C. G. Darwin, Prof. H. M. Fox, Dr. H. J. Gough, Dr. A. D. Imms, Prof. C. K. Ingold, Prof. G. B. Jeffery, Prof. R. T. Leiper, Prof. H. S. Raper, Sir Owen Richardson, Prof. E. K. Rideal, Dr. F. J. W. Roughton, Prof. W. W. C. Toploy, Prof. R. Whiddington.

\section{Announcements}

Dr. J. B. Mennel, president of the Section of Physical Medicine of the Royal Society of Medicine, has been awarded a gold key by the American Congress of Physical Therapy for distinguished research on physical therapy during the last year.

DR. ALFRED Froenulch, formerly professor of pharmacology in the University of Vienna, has been appointed pharmacologist to the May Instituto for Medical Research of the Jewish Hospital, Cincinnati.

The name of the National Baby Week Council, a body which camo into existence during the War of 1914-18, is now changed to "National Baby Welfare Council", this name being more commensurate with the increased scope of work falling to the Council's lot under war conditions. The address of the National Baby Welfare Council is 29 Gordon Square, London, IV.C.1.

THe Women's Medical Association of New York offers a Mary Putnam Jacobi fellowship to any woman doctor, American or foreign, to carry on or complete some special problems in medical research. Application should be made by March 1, 1940, to the secretary, Dr. Phebe L. Dubois, 150 East 73rd Street, Now York City.

In his latest quarterly report the Registrar-General states that the number of live births in England and Wales during the thirteen weeks ended June 30 was 222 more than in the corresponding quarter of 1938 , and amounted to an annual birth-rate of 16 per thousand of the population. The number of deaths corresponded to an annual rate of $11 \cdot 7$, and the mortality of infants under one year of age to an annual rate of 48 , which was 8 below the average of the preceding ten second quarters. 